\title{
Neonatal imperforate hymen with hydrocolpos
}

\author{
Manisha Ramphul, Luke Perry, Charu Bhatia
}

Lister Hospital, East and North Hertfordshire Trust, Stevenage, UK

\section{Correspondence to Dr Manisha Ramphul,} manisha.ramphul@nhs.net

Accepted 11 May 2016

\section{DESCRIPTION}

A $34+4$ weeks neonate was born by spontaneous vaginal delivery with normal antenatal scans. Routine neonatal examination revealed the absence of a vaginal opening with bulging of vaginal introitus (figure 1). Urethral and anal openings were patent. A provisional diagnosis of an imperforate hymen with hydrocolpos was considered.

Subsequent investigations revealed a deranged renal function at 22 hours of life (creatinine $99 \mu \mathrm{mol} / \mathrm{L}$, urea $10.2 \mathrm{mmol} / \mathrm{L}, \mathrm{K} 6.6 \mathrm{mmol} / \mathrm{L}$ and $\mathrm{Na} 132 \mathrm{mmol} / \mathrm{L})$. An urgent abdominal ultrasound was arranged to rule out hydronephrosis. The kidneys and lower genitourinary tract were normal.

The imperforate hymen was managed surgically through a hymenal incision. Subsequently, the external female genitalia appeared normal (figure 2) and the renal function normalised. A positive family history was noted with an elder sibling who also had an imperforate hymen, which was surgically treated at 5 months.

The incidence of imperforate hymen is estimated at $0.014-0.1 \%$ and presentation is often late with amenorrhea in adolescence. Hydrocolpos is cystic dilation of the vagina with fluid accumulation due to stimulation of secretory glands of the reproductive tract secondary to vaginal obstruction. Hydrocolpos may lead to obstructive uropathy through the compression of the lower urinary tract, resulting in hydronephrosis and hydroureters. ${ }^{1}$ Hence early detection is essential as it could be

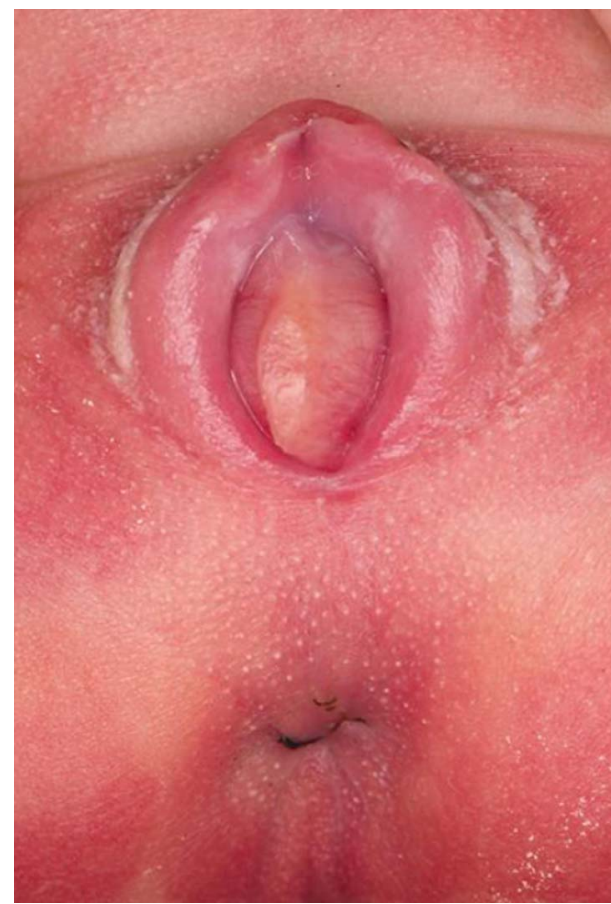

Figure 1 Imperforate hymen noted at birth.

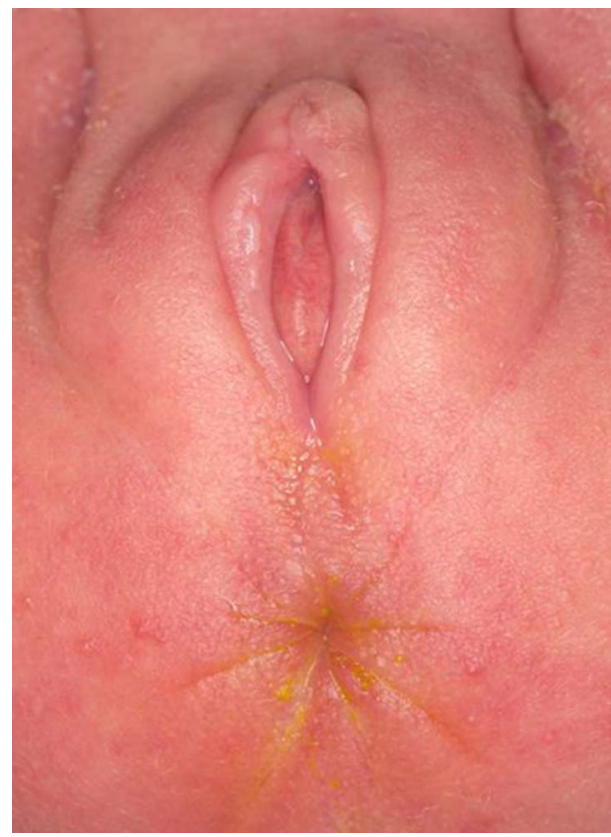

Figure 2 Appearance of perineum after surgical management.

associated with life-threatening renal failure. ${ }^{2}$ As observed in our report, cases of familial recurrence have been reported. ${ }^{3}$

A thorough newborn examination is essential to screen for an imperforate hymen, which can result in renal complications in the neonatal period.

\section{Learning points}

- A thorough newborn screening examination may enable the detection of rare conditions such as imperforate hymen presenting in the neonatal period.

- An imperforate hymen usually presents in adolescence with amenorrhoea, but may be detected in the neonatal period.

- Hydrocolpos associated with an imperforate hymen can cause renal failure.

Contributors MR and CB conceived the idea. LP wrote the first draft of the article. MR and CB participated in revising the manuscript and all authors approved the final submitted version.

Competing interests None declared.

Patient consent Obtained.

Provenance and peer review Not commissioned; externally peer reviewed. 


\section{REFERENCES}

1 Eksioglu AS, Maden HA, Vinar G, et al. Imperforate hymen causing bilateral hydroureteronephrosis in an infant with bicornuate uterus. Case Rep Urol 2012;2012:102683.
2 Nagai K, Murakami Y, Nagatani K, et al. Life-threatening acute renal failure due to imperforate hymen in an infant. Pediatr Int 2012;54:280-2.

3 Sakalkale R, Samarakkody U. Familial occurrence of imperforate hymen. J Pediatr Adolesc Gynecol 2005;18:427-9.

Copyright 2016 BMJ Publishing Group. All rights reserved. For permission to reuse any of this content visit

http://group.bmj.com/group/rights-licensing/permissions.

BMJ Case Report Fellows may re-use this article for personal use and teaching without any further permission.

Become a Fellow of BMJ Case Reports today and you can:

- Submit as many cases as you like

- Enjoy fast sympathetic peer review and rapid publication of accepted articles

- Access all the published articles

- Re-use any of the published material for personal use and teaching without further permission

For information on Institutional Fellowships contact consortiasales@bmjgroup.com

Visit casereports.bmj.com for more articles like this and to become a Fellow 